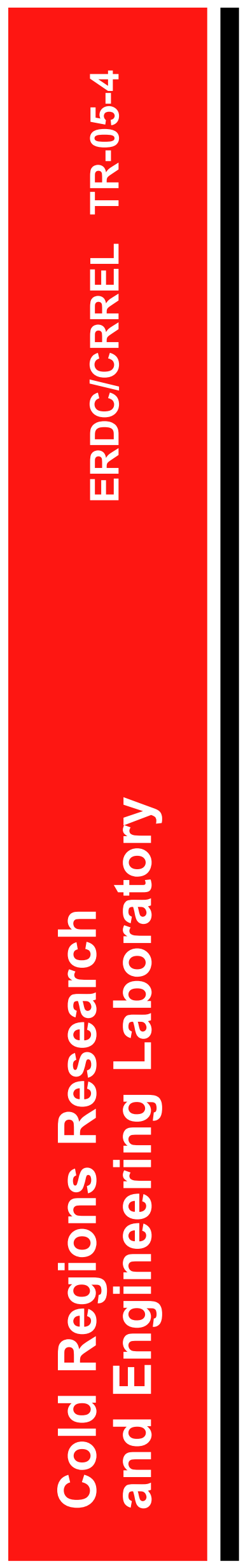

\title{
Microbial Community Shifts Associated with RDX Loss in a Saturated and Well-Drained Surface Soil
}

David B. Ringelberg, Charles M. Reynolds, Karen L. Foley,

March 2005

and Lawrence B. Perry 
ERDC/CRREL TR-05-4

March 2005

\section{Microbial Community Shifts Associated with RDX Loss in a Saturated and Well-Drained Surface Soil}

David B. Ringelberg, Charles M. Reynolds, Karen L. Foley, and Lawrence B. Perry

Engineer Research and Development Center

Cold Regions Research and Engineering Laboratory

72 Lyme Road

Hanover, New Hampshire 03755

Approved for public release; distribution is unlimited.

Prepared for OFFICE OF THE CHIEF OF ENGINEERS 


\section{ABSTRACT}

Low-order, incomplete detonations can deposit hexahydro-1,3,5- trinitro- 1,3,5-triazine (RDX) into training range surface soils. In previous work, we showed that aqueous RDX could be rapidly biotransformed (4-day half-life) in water-saturated surface soil. However, biotransformation rates in the same soil at 0.15 -bar soil moisture tension were significantly slower (28-day half-life). Here we report on the microbial community composition associated with the deposited RDX under the differing soil moisture tensions. Phospholipid fatty acid (PLFA) and terminal fragment length polymorphism (T-RFLP) profiles were used to quantify the in situ microbiota. The rapid biotransformation of RDX in the saturated soil was coincident with an endpoint microbial community containing firmicutes $(36 \%)$, proteobacteria $(54 \%)$, actinobacteria $(8 \%)$, and bacteroidetes $(1 \%)$. The unsaturated soil contained a greater number of genera (2.5 times that of the saturated soil) within similar phyla ( $19 \%$ firmicutes, $66 \%$ proteobacteria, $6 \%$ actinobacteria, $2 \%$ bacteroidetes, and $7 \%$ chlorobi). Significant differences between the two moisture contents occurred within the proteobacteria and firmicutes. A 37\% gamma-class in unsaturated soil shifted to $56 \%$ alpha- and delta-classes in saturated soil. Total firmicutes increased from $19 \%$ unsaturated to $36 \%$ saturated. PLFA profiles extracted from saturated soil showed an increase in the relative abundance of only a few fatty acids (n16:0, n18:0, i15:0, a15:0, b16:1w7c, n18:1w9c, n18:1w7c, and cy19:0). However, these PLFAs are consistent with Gram-negative proteobacteria (n16:1w7c, n18:1w9c, and n18:1w7c) and firmicutes (i15:0 and a15:0). Based on these results, we hypothesize that the saturated soil led to the development of alpha/deltaproteobacteria and firmicute subpopulations and that these populations were primarily responsible for the observed biological transformation of RDX.

DISCLAIMER: The contents of this report are not to be used for advertising, publication, or promotional purposes. Citation of trade names does not constitute an official endorsement or approval of the use of such commercial products. All product names and trademarks cited are the property of their respective owners. The findings of this report are not to be construed as an official Department of the Army position unless so designated by other authorized documents. 


\section{CONTENTS}

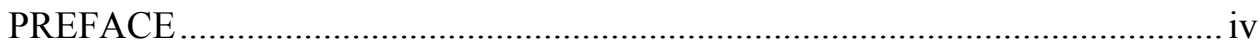

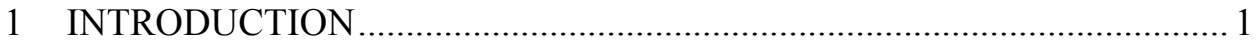

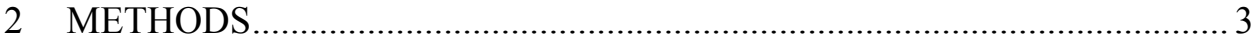

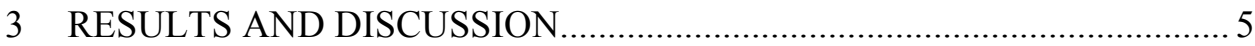

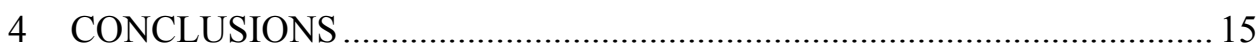

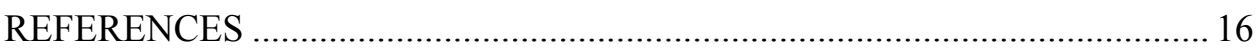

\section{ILLUSTRATIONS}

Figure 1. Loss of RDX from saturated and unsaturated training range surface soil

Figure 2. Relative change in phospholipid fatty acids in saturated and unsaturated training range surface soils exposed to $10 \mathrm{mg} \mathrm{L}^{-1}$ of aqueous RDX

Figure 3. Distribution of bacteria phyla and bacterial classes within the proteobacteria phylum in saturated and unsaturated training range surface soils following 840 hours of incubation

Figure 4. Changes in total microbial biomass and relative percentages of bacterial PLFA in an unsaturated training range surface soil following 840 hours of incubation in the presence of $10 \mathrm{mg} \mathrm{kg}^{-1}$ of aqueous RDX

\section{TABLES}

Table 1. PLFA biomarkers detected in Ft. Greely surface soils incubated under different soil moisture tensions

Table 2. Total microbial biomass and percentages of biomarker and individual PLFAs detected in Ft. Greely surface soils following 840 hours of incubation in the presence of $10 \mathrm{mg} \mathrm{kg}^{-1}$ of RDX under saturated and unsaturated soil moisture tensions 9

Table 3. Bacteria identified in the saturated and unsaturated training range surface soils 


\section{PREFACE}

This report was prepared by David B. Ringelberg, Research Physical Scientist; Dr. Charles M. Reynolds, Research Physical Scientist; Karen L. Foley, Biological Science Technician; and Lawrence B. Perry, Lead Physical Sciences Technician, all of the Environmental Sciences Branch, Cold Regions Research and Engineering Laboratory (CRREL), U.S. Army Engineer Research and Development Center (ERDC), Hanover, New Hampshire.

The authors thank Dr. Thomas Jenkins and Marianne Walsh; without their technical assistance and insight, this work would not have been possible. They also acknowledge the assistance of Lauren Raymond in sample preparation. This work was funded through the U.S. Army Engineer Research and Development Center, Environmental Laboratory, Basic Research Program Office, administered by Dr. John Cullinane.

This report was prepared under the general supervision of Lawrence Gatto, Acting Chief, Environmental Sciences Branch; Dr. Lance Hansen, Deputy Director; and James L. Wuebben, Acting Director, CRREL.

The Commander and Executive Director of the Engineering Research and Development Center is COL James R. Rowan. The Director is Dr. James R. Houston. 


\title{
Microbial Community Shifts Associated with RDX Loss in a Saturated and Well-Drained Surface Soil
}

\author{
DAVID B. RINGELBERG, CHARLES M. REYNOLDS, \\ KAREN L. FOLEY, AND LAWRENCE B. PERRY
}

\section{INTRODUCTION}

Little is known about how microbial communities and/or populations evolve in the environment. It is becoming clear that microbes form organized groups, with each group performing a separate and often complementary activity. The community as a whole often has properties that supersede any of its individual members. The development of microbial communities in the presence of environmental pollutants is an active field of study. A considerable number of bacterial species that show the ability to degrade a multitude of pollutants have been isolated from numerous environments. However, no bacterial species exists in nature alone, so any examination of contaminant fate in the environment would benefit from the examination of the microbial community as a whole or as an aggregate sum of individual organized groups.

Hexahydro-1,3,5-trinitro-1,3,5-triazine (RDX) can pose a threat to human health. Although there are limited data on long-term effects from low-level exposures, acute exposure can result in seizures (ATSDR 1995). RDX is soluble in water at $40 \mathrm{mg} \mathrm{L}^{-1}$, and the organic carbon-normalized soil sorption coefficients $\left(K_{\mathrm{oc}}\right)$ range from 63 to 270, placing RDX in a classification as a medium- to highmobility compound (Price et al. 2001, Spanggord et al. 1983). The threat of potential groundwater contamination persuaded the Environmental Protection Agency to close the Massachusetts Military Range to open detonations in 1998. Although closing a military base because of concerns over groundwater contamination may alleviate the potential impacts on human health, the closure also has a negative impact on military training and readiness. These opposing issues highlight the importance of developing a clear understanding of the fate of explosives in training facility soils.

RDX is susceptible to biodegradation by both bacteria and fungi (Speitel et al. 2001, Stahl et al. 2001). For bacteria, anaerobic degradation appears to be the 
preferential pathway, yet recent findings have demonstrated significant degradation under aerobic conditions (Sheremata and Hawari 2000, Sheremata et al. 2001). Although knowledge of biotic RDX degradation processes is growing, there are still many unknowns regarding the enzymatic pathways involved (Hawari 2000).

In this study, we examined the response of a soil microbiota to the presence of RDX under differing soil water potentials. Our previous work demonstrated that RDX biodegradation proceeded at a rate seven times faster under watersaturated versus unsaturated conditions (Ringelberg et al. 2003). Here we show that the biotransformation of RDX was coincident with the evolution of a unique microbial community composition and that this community was enriched in individual bacteria containing specific or associated nitramine biodegradation capabilities. 


\section{METHODS}

Surface soil was collected at Ft. Greely, Alaska. Ft. Greely is located approximately 100 miles southeast of Fairbanks and 350 miles northeast of Anchorage. The soil was homogenized, passed through a 4.7-mm sieve, and completely air-dried at $45^{\circ} \mathrm{C}$ for 18 hours prior to use. Selected physico-chemo parameters of the soil were $58 \%$ sand, $35 \%$ silt, $7 \%$ clay, $\mathrm{pH} 6.7$, organic matter $10.4 \%$ (on a dry weight basis), $\mathrm{NO}_{3}-\mathrm{N} 4 \mathrm{mg} \mathrm{kg}^{-1}, \mathrm{NH}_{4}-\mathrm{N} 5 \mathrm{mg} \mathrm{kg}^{-1}$, phosphorus $4 \mathrm{mg} \mathrm{kg}^{-1}$, potassium $34 \mathrm{mg} \mathrm{kg}^{-1}$, and $\mathrm{Fe} 0.25 \mathrm{mg} \mathrm{kg}^{-1}$. Soil analyses were performed at the University of New Hampshire analytical services lab (Durham, $\mathrm{NH})$.

Dry soils (5 g each) were pre-incubated in $40-\mathrm{mL}$ vials in $1 \mathrm{~mL}$ of $\mathrm{H}_{2} \mathrm{O}$ (Milli-Q grade) at room temperature $\left(21^{\circ} \mathrm{C} \pm 2^{\circ} \mathrm{C}\right)$ for 48 hours to acclimate the system prior to RDX addition. Individual microcosms were then augmented with 2 or $25 \mathrm{~mL}$ of aqueous RDX (unsaturated and saturated, respectively). The final concentration of the added aqueous RDX was $10 \mathrm{mg} \mathrm{L}^{-1}$. The saturated microcosms also received $100 \mu \mathrm{L}$ of a $0.1 \%$ resazurin solution as a redox indicator. Control (attenuated) microcosms were established by autoclaving $\left(120^{\circ} \mathrm{C}\right.$ for 20 minutes) replicate unsaturated and saturated microcosms three times, with an 8hour resting or growth period between sterilizations.

Following the RDX addition, the microcosms were incubated for 840 hours in the dark without agitation at room temperature $\left(21^{\circ} \mathrm{C} \pm 2^{\circ} \mathrm{C}\right)$. Three replicate vials were sacrificed at $0,48,168,504$, and 840 hours to obtain microbiological and contaminant chemistry data. The recovery and analysis of soluble and extractable RDX was as described in Ringelberg et al. (2003). Briefly, solids were extracted in $10 \mathrm{~mL}$ of ACN with sonication for 18 hours at $20^{\circ} \mathrm{C}$. Saturated microcosms were centrifuged for 20 minutes at $2000 \mathrm{rpm}$ prior to extraction. ACN extracts, as well as the aqueous phase of the saturated microcosms, were then diluted and filtered (0.45- $\mu \mathrm{m}$ Millipore filter, Millex-FH, Bedford, MA) prior to analysis by HPLC. RDX and nitroso intermediates were quantified on a $15-\mathrm{cm} \times 3.9-\mathrm{cm}(4-\mu \mathrm{m})$ Nova Pak C8 (Waters Millipore) column by elution in $1.5 \mathrm{~mL} \mathrm{~min} .^{-1}$ of 15:85 isopropanol: $\mathrm{H}_{2} \mathrm{O}(\mathrm{v}: \mathrm{v})$. Absorbance at $254 \mathrm{~nm}$ was recorded. Nitroso intermediates were confirmed by elution in $1.2 \mathrm{~mL} \mathrm{~min}^{-1}$ of 12:23:62 methanol- $\mathrm{ACN}-\mathrm{H}_{2} \mathrm{O}$ off a $25-\mathrm{cm} \times 4.6-\mathrm{mm}(5-\mu \mathrm{m})$ cyano (Supelco LC-CN) column.

Ester-linked polar lipid fatty acids (PLFA) were recovered and quantified as described in White and Ringelberg (1998). Approximately $1-1.5 \mathrm{~g}$ of wet soil was extracted in $3.8 \mathrm{~mL}$ of methanol:chloroform:phosphate buffer $(2: 1: 0.8$, 
$\mathrm{v}: \mathrm{v}: \mathrm{v})$. The total lipid extract was then fractionated using solid-phase column chromatography (Pinkart et al. 1998). Polar lipids were then transesterified into methyl esters prior to separation and identification by gas chromatography/mass spectrometry. Individual PLFAs were quantified on a $30-\mathrm{m} \times 0.25-\mathrm{mm}(0.25-$ $\mu \mathrm{m})$ HP-5MS (Agilent) coupled to a 5973 mass selective detector (Agilent).

Terminal restriction length polymorphisms (T-RFLP) were analyzed as described by Gruntzig et al. (2002). DNA was recovered with the UltraClean Soil DNA kit (MoBio Laboratories) per the manufacturer's directions. A portion of the 16S rDNA gene was amplified with primers 8F (FAM labeled) and 926R (HEX labeled). The PCR amplicon was cleaned using the QIAquick PCR purification kit (Qiagen) per the manufacturer's direction. The restriction enzymes MspI, RsaI, and HhaI (Promega) were used to digest approximately $150 \mathrm{ng}$ of the purified PCR product. The digests were then desalted using the QIAquick Nucleotide Removal Kit (Qiagen) per the manufacturer's directions. Equal amounts of purified digest $\left(\sim 100 \mathrm{ng} \mu \mathrm{L}^{-1}\right)$ were then run on a 310 Genetic Analyzer (ABI) equipped with a $45-\mathrm{cm}$ capillary filled with POP-4 polymer. Samples were injected electrokinetically for $30 \mathrm{~s}$ at $15 \mathrm{kV}$. Peaks were sized against a MapMarker 1000 standard (Bioventures). Only the final time points ( 840 hours) were analyzed, and only fragments exceeding a fluorescent threshold of 100 and common to all three replicates were used for further analyses. Taxonomic identifications were obtained using the phylogenetic analysis tool (PAT) algorithm (http://trflp.limnology.wisc.edu) run against entries contained within the ribosomal database project (http://rdp.cme.msu.edu).

Analyses of variance (ANOVAs) were conducted on PLFA molar percentages using commercial software (Statistica v.6.0, StatSoft, Inc., Tulsa, OK). Post hoc analyses for significance $(\alpha=0.05)$ were made using the Tukey honest significant difference method. Discriminant analyses were conducted on arcsintransformed PLFA molar percentages using JMP Discovery software (v.5.0, SAS Institute, Cary, NC). 


\section{RESULTS AND DISCUSSION}

The soil used in this study had a demonstrated capacity for the biological transformation of RDX (Ringelberg et al. 2003). Significant differences in RDX loss were measured between attenuated and active microcosms at two soil water potentials (Fig. 1). Complete loss of the parent RDX occurred after 504 hours of incubation in a saturated soil, and a $58 \%$ loss occurred after 840 hours of incubation in an unsaturated soil ( 0.15 bar soil moisture tension). RDX half-lives at the two soil moisture levels tested were 4 days (saturated) and 29 days (unsaturated). These values are similar to those reported by Zhao et al. (2004) for aqueous RDX in a marine sediment (at $10^{\circ} \mathrm{C}$ ) and by Spietel et al. (2001) for RDX in a soil at a gravimetric moisture level of $8 \%$. Others have also shown that soil microbial populations are capable of biotransforming or biodegrading RDX under saturated and unsaturated conditions (Light et al. 1997, Boopathy et al. 1998, Guiot et al.
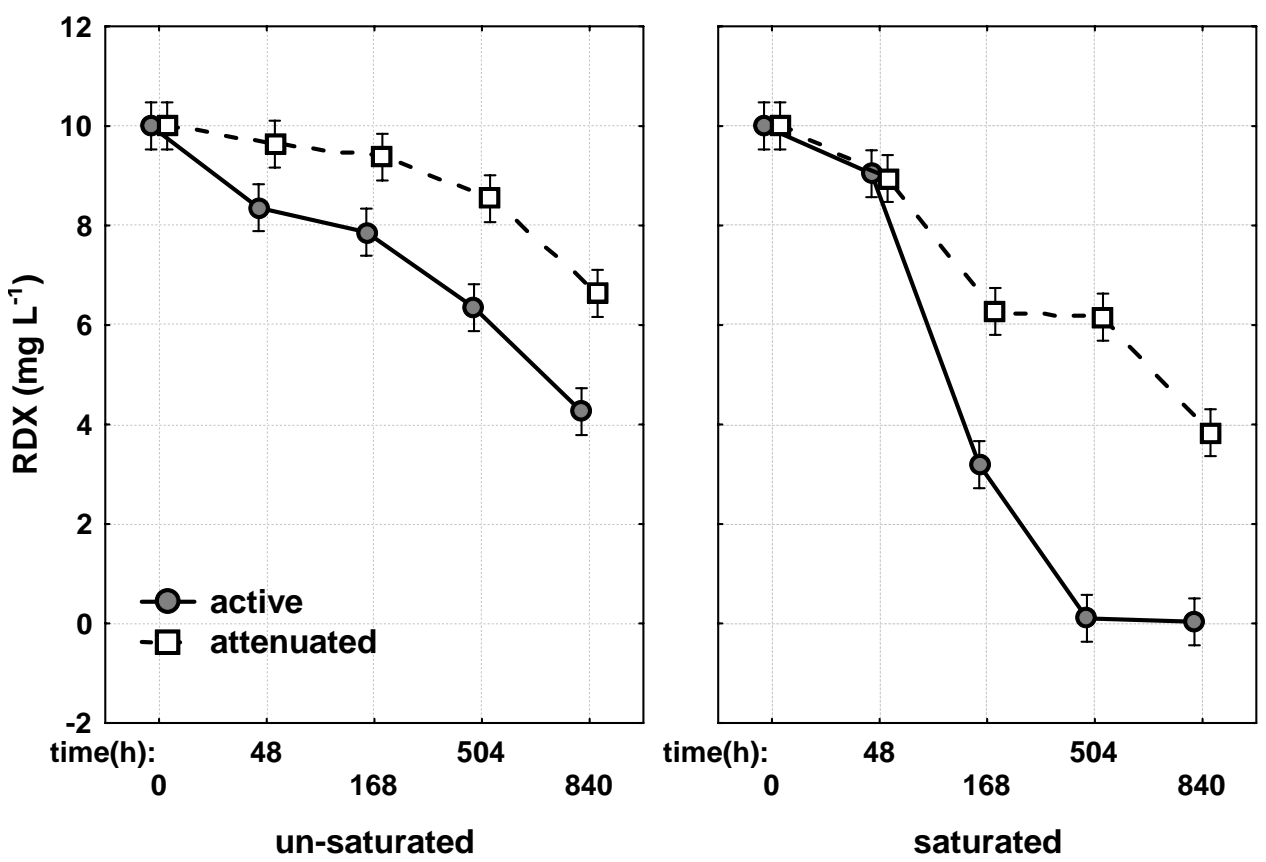

Figure 1. Loss of RDX from saturated and unsaturated training range surface soil. The soils were sieved $(2 \mathrm{~mm})$, homogenized, and air dried prior to saturation and moistening ( 0.15 bar) with aqueous $\mathrm{RDX}$ at $10 \mathrm{mg} \mathrm{L}^{-1}$. The soils were incubated for 840 hours at room temperature $\left(28^{\circ} \mathrm{C}\right)$ in the dark. Attenuated samples were autoclaved three times, with a standing period between each sterilization. RDX biotransformation occurred at both soil moistures. The rate of RDX biotransformation was seven times greater in the saturated soil. The vertical bars denote a 0.95 confidence interval. 
1999, Sheremata et al. 2001). The in situ microbial community composition was one variable not examined in any of these past reports. Therefore, no attempt was made to relate community composition to RDX biotransformation/ biodegradation.

A number of reports have shown that reduced soil conditions are ideal for RDX biodegradation (McCormick et al. 1981, Boopathy et al. 1998, Guiot et al. 1999, Spietel et al. 2001). Saturated soils can rapidly become anoxic given a sufficient biomass and bio-available carbon. In such a situation, microbes consume the available oxygen more rapidly than it can be replenished via diffusion. In this study, following 48 hours of pre-incubation, the microbial biomass (approximately $10^{8}$ cells g ${ }^{-1}$ or $20-30 \mathrm{nmol} \mathrm{g}^{-1}$ PLFA) in the saturated microcosms was shown to be sufficient to reduce the saturated soil within 72 hours (Ringelberg et al. 2003, Balkwill et al. 1988). This was indicated by a color change in the added resazurin dye. Although it is also possible that reduced micro-sites formed within the unsaturated soil, it was assumed that $\mathrm{O}_{2}$ was not limiting in these microcosms. The differences in water potential were found to have an effect on soil redox (oxygen depletion), which coincided with a change in the in situ rates of RDX biotransformation/biodegradation. RDX loss was then attributed to two corresponding processes: mass transfer (bioavailability) and a shift in the extant microbiota (i.e. an enrichment in RDX degraders). Since the microcosms were not mixed during the incubation period and RDX was added at an equal concentration, a shift in the extant community was considered the more heavily weighted variable.

Our previous work showed that the microbiota in the saturated soil reduced RDX via the formation of nitroso intermediates. Nitrosos are intermediates in the anaerobic catabolic pathway for RDX biodegradation first described by McCormick et al. in 1981. We did not detect nitroso intermediates in the unsaturated soil, suggesting that RDX biotransformation/biodegradation in this soil proceeded by another pathway. Hawari et al. (2000) suggested that an aerobic enzymatic attack of the $\mathrm{H}-\mathrm{NO}_{2}$ or $\mathrm{C}-\mathrm{H}$ bonds in $\mathrm{RDX}$ could lead to the formation of unstable intermediates that subsequently undergo spontaneous decomposition. To date, no organism has been isolated that is metabolically capable of both pathways. Therefore, there should be taxonomic differences in the microbiota related to RDX biotransformation/degradation for the two soil moisture conditions.

Bacterial membranes are primarily composed of phospholipids. The associated fatty acids (PLFAs) differ enough among genera and species to allow for taxonomic identifications (Onderdonk and Sasser 1995). In community analyses, quantified PLFA profiles can be used to define taxonomic responses to contaminant exposures (Ringelberg et al. 2001). A plot of saturated vs. unsaturated PLFA 
showed a dramatic shift in the saturated PLFA profile over the course of the study (Fig. 2). Relative to the unsaturated soil, very few PLFAs became enriched under the saturated condition. Those PLFAs that did included n16:0 and n18:0, the Gram-positive biomarker a15:0, and the Gram-negative biomarkers 18:1 $107 \mathrm{c}$ and cy 19:0 (see Table 1 for an association of PLFA with microbial taxonomy). The endpoint ( 840 hours) saturated PLFA profile reflects the development of subpopulations of Gram-positive (a15:0) and Gram-negative bacteria ( $\omega 7$ fatty acids), but it also indicates a dramatic loss in the total number of PLFAs detected. The total number of PLFAs often correlates with microbial diversity and, in this analysis, would indicate a decrease in diversity (Table 2). The total microbial biomass in the saturated soil at 840 hours was also $1 / 3$ that of the unsaturated soil (Table 2). Although microbial biomass in the saturated soil was $1 / 3$ lower than that observed in the unsaturated soil, the detection limits of the instrument were not approached. Both soils showed final cell numbers of $10^{8}$ cells $\mathrm{g}^{-1}$, which is typical of a surface soil (Conklin 2002).

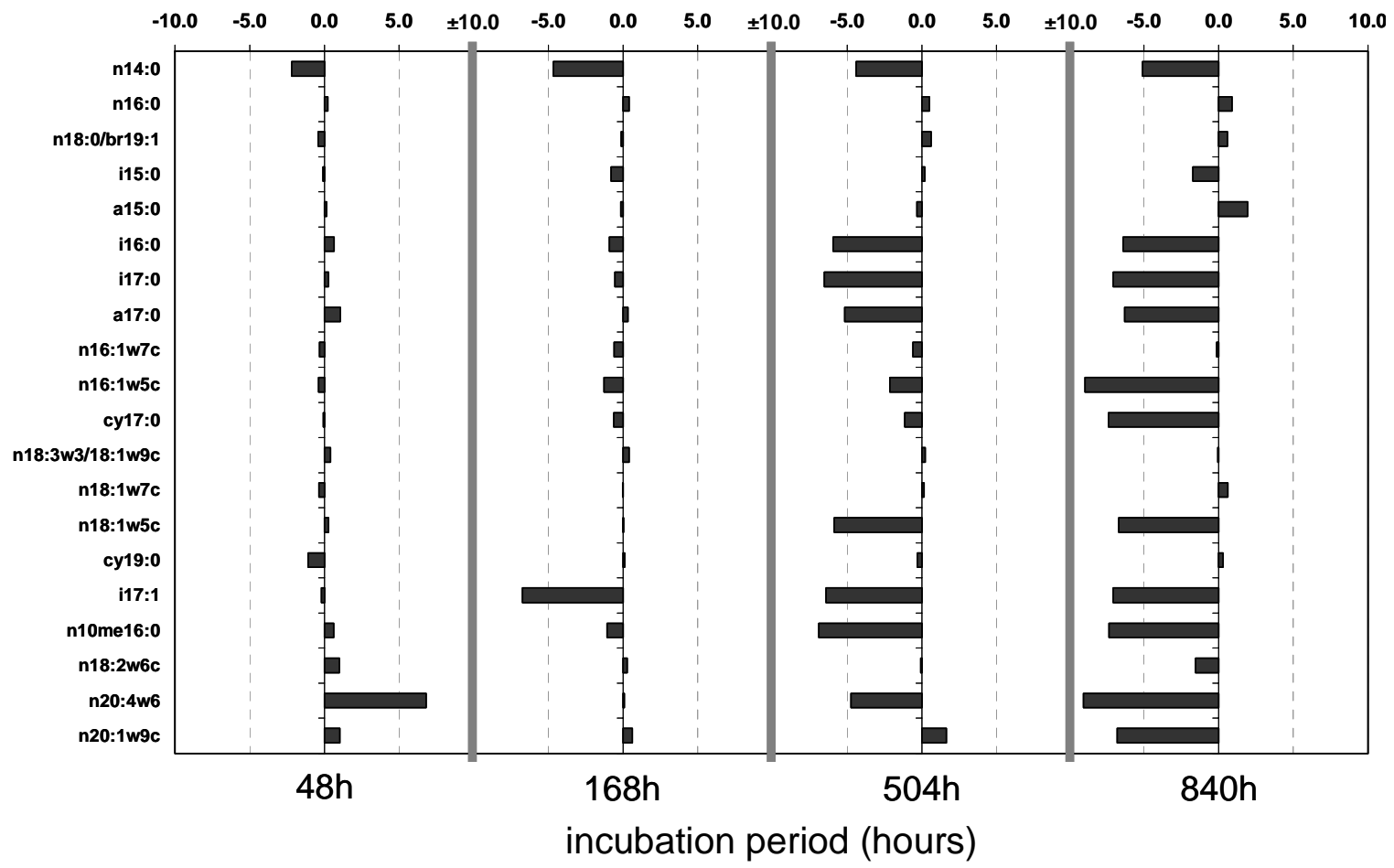

Figure 2. Relative change in phospholipid fatty acids (PLFAs) in saturated and unsaturated training range surface soils exposed to $10 \mathrm{mg} \mathrm{L}^{-1}$ of aqueous RDX. The data (mole \%) are expressed on a log2 scale to highlight fold changes that occurred between the specified incubation periods. Relative to the unsaturated soil, only a few PLFAs were enriched in the saturated soil. These included the Gram-positive bacterial biomarker a15:0 and the Gram-negative bacterial biomarkers n18:1 $\omega 7 \mathrm{c}$ and cy19:0. 
Table 1. PLFA biomarkers detected in Ft. Greely surface soils incubated under different soil moisture tensions.

\begin{tabular}{|cll|}
\hline \multicolumn{2}{c}{ Organisms } & \multicolumn{1}{c|}{ PLFA biomarkers $^{*}$} \\
\hline Eukaryotes & $\omega 6$ series & $\mathrm{n} 18: 2 \omega 6 \mathrm{c}, \mathrm{n} 20: 4 \omega 6 \mathrm{c}$ \\
& $\omega 3$ series & $\mathrm{n} 18: 3 \omega 3, \mathrm{n} 20: 5 \omega 3$ \\
Prokaryotes & Gram-positive & $\mathrm{i} 14: 0, \mathrm{a} 15: 0, \mathrm{i} 16: 0, \mathrm{i} 17: 0, \mathrm{a} 17: 0$ \\
& Gram-negative & \\
Cyclopropyl & $\mathrm{cy} 17: 0, \mathrm{cy} 19: 0$ \\
$\omega 7$ series & $\mathrm{n} 16: 1 \omega 7 \mathrm{c}, \mathrm{n} 18: 1 \omega 7 \mathrm{c}$ \\
Other series & $\mathrm{n} 16: 1 \omega 9 \mathrm{c}, \mathrm{n} 16: 1 \omega 5 \mathrm{c}, \mathrm{n} 17: 1 \omega 8 \mathrm{c}, \mathrm{n} 18: 1 \omega 9 \mathrm{c}$ \\
& & $\mathrm{n} 18: 1 \omega 5 \mathrm{c}, \mathrm{n} 19: 1 \omega 8 \mathrm{c}, \mathrm{n} 20: 1 \omega 9 \mathrm{c}$ \\
& Actinomycetes & $\mathrm{n} 10 \mathrm{me} 16: 0, \mathrm{n} 10 \mathrm{me} 17: 0, \mathrm{n} 10 \mathrm{me} 18: 0, \mathrm{i} 17: 1 \mathrm{w} 7 \mathrm{c}$ \\
\hline
\end{tabular}

*PLFA biomarkers are assigned to taxonomy according to Rock and Cronan (1985), Lechevalier and Lechevalier (1988), Carpenter-Boggs et al. (1998), and Pinkart et al. (2002).

To specifically address diversity and to further resolve the in situ microbial community descriptions, the T-RFLP assay was applied. Size fragments from three restriction digests (HhaI, MspI, and RsaI) of the 8f-926r 16S rDNA amplicon were imported into the web-based phylogenetic assignment tool (PAT) for a taxonomic query using Ribosomal Database Project (RDP) entries. The results of the query are listed in Table 2 . The diversity of bacterial species identified in the saturated soils was approximately $60 \%$ less than that observed in unsaturated soil (32 species in unsaturated soil versus 13 species in saturated soil). This is the same loss in diversity indicated by the PLFA analysis.

The T-RFLP analysis identified firmicutes (36\%), proteobacteria (54\%), actinobacteria $(8 \%)$, and bacteroidetes $(1 \%)$ in the endpoint microbial community in the saturated soil. The unsaturated soil contained a greater number of genera (2.5 times that of the saturated soil) within similar phyla (19\% firmicutes, $66 \%$ proteobacteria, $6 \%$ actinobacteria, $2 \%$ bacteroidetes, and $7 \%$ chlorobi). Microbial community development within the saturated soil was characterized by a shift toward bacterial species of the phylum Firmicutes and alpha- and delta-classes of the phylum Protoeobacteria (Fig. 3). The increase in Gram-positive firmicutes from $19 \%$ (unsaturated) to $36 \%$ (saturated) corresponded with the PLFA biomarker analysis (i.e. enrichment in a15:0). Two related species, Sporosarcina urea and Halobacillus halophilus, were identified as the most abundant (identifiable) bacteria present in the saturated soil (Table 3). Both species tolerate high salt concentrations, have the ability to synthesize urease, and form endospores. These species are widely distributed in surface soils. 
Table 2. Total microbial biomass (nmol g ${ }^{-1}$ ) and percentages (mol\%) of biomarker and individual PLFAs detected in Ft. Greely surface soils following 840 hours of incubation in the presence of $10 \mathrm{mg} \mathrm{kg}^{-1}$ of RDX under saturated and unsaturated $(0.15$ bar $)$ soil moisture tensions.

\begin{tabular}{|c|c|c|c|c|}
\hline & un-s & ated & sat & \\
\hline & mean & s.d. & mean & s.d. \\
\hline biomass (nmol g-1) & 38.9 & 7.9 & 13.4 & 0.4 \\
\hline Microbial Class (mol\%) & & & & \\
\hline Total eukaryotes & 16.0 & 1.9 & 3.0 & 0.2 \\
\hline$\omega 3$ & 0.8 & 0.4 & - & - \\
\hline$\omega 6$ & 14.0 & 2.3 & 3.0 & 0.2 \\
\hline Total Gram-positive & 6.3 & 0.4 & 4.9 & 0.3 \\
\hline Total Gram-negative & 46.5 & 0.3 & 44.3 & 1.0 \\
\hline$\omega 7$ series & 19.6 & 0.5 & 27.4 & 0.8 \\
\hline other series & 21.1 & 0.6 & 11.7 & 0.2 \\
\hline cyclopropyl & 5.8 & 0.5 & 5.2 & 0.4 \\
\hline actinomycetes & 3.4 & 1.4 & - & - \\
\hline PLFA (mol\%) & & & & \\
\hline $\mathrm{n} 14: 0$ & 0.3 & 0.3 & - & - \\
\hline $\mathrm{n} 15: 0$ & 0.2 & 0.3 & - & - \\
\hline $\mathrm{n} 16: 0$ & 21.2 & 1.3 & 40.0 & 1.4 \\
\hline $\mathrm{n} 17: 0$ & 0.4 & 0.6 & - & - \\
\hline $\mathrm{n} 18: 0$ & 5.2 & 0.3 & 7.8 & 0.5 \\
\hline $\mathrm{n} 20: 0$ & 0.5 & 0.9 & - & - \\
\hline i15:0 & 2.2 & 0.0 & 0.7 & 1.2 \\
\hline a15:0 & 1.1 & 0.1 & 4.3 & 0.9 \\
\hline i16:0 & 0.8 & 0.1 & - & - \\
\hline i17:0 & 1.3 & 0.2 & - & - \\
\hline a17:0 & 0.8 & 0.1 & - & - \\
\hline $\mathrm{n} 16: 1 \omega 9 \mathrm{c}$ & 0.6 & 0.1 & - & - \\
\hline $\mathrm{n} 16: 1 \omega 7 \mathrm{c}$ & 4.6 & 0.0 & 4.3 & 0.2 \\
\hline $\mathrm{n} 16: 1 \omega 5 \mathrm{c}$ & 4.9 & 0.2 & - & - \\
\hline $\mathrm{n} 17: 1 \omega 8 \mathrm{c}$ & 0.5 & 0.4 & - & - \\
\hline cy17:0 & 1.6 & 0.4 & - & - \\
\hline $\mathrm{n} 18: 1 \omega 9 \mathrm{c} / 13: 3 \omega 3$ & 12.1 & 1.1 & 11.7 & 0.2 \\
\hline $\mathrm{n} 18: 1 \omega 7 \mathrm{c}$ & 15.0 & 0.4 & 23.1 & 1.0 \\
\hline $\mathrm{n} 18: 1 \omega 5 \mathrm{c}$ & 1.0 & 0.3 & - & - \\
\hline$n 19: 1 \omega 8 c$ & 1.0 & 0.3 & - & - \\
\hline cy19:0 & 4.2 & 0.2 & 5.2 & 0.4 \\
\hline $\mathrm{n} 20: 1 \omega 9 \mathrm{c}$ & 1.1 & 0.2 & - & - \\
\hline i17:1 & 1.3 & 0.3 & - & - \\
\hline n10me16:0 & 1.6 & 0.3 & - & - \\
\hline n10me18:0 & 0.5 & 0.9 & - & - \\
\hline $\mathrm{n} 18: 2$ & 0.8 & 0.2 & - & - \\
\hline $\mathrm{n} 18: 2 \omega 6 \mathrm{c}$ & 8.8 & 1.2 & 3.0 & 0.2 \\
\hline $\mathrm{n} 20: 4 \omega 6$ & 5.2 & 1.0 & - & - \\
\hline $\mathrm{n} 20: 5 \omega 3$ & 0.8 & 0.4 & - & - \\
\hline $\mathrm{n} 20: 2$ & 0.3 & 0.4 & - & - \\
\hline
\end{tabular}


Table 3. Bacteria identified in the saturated and unsaturated training range surface soils. Identifications are based on matching T-RFLP fragments from three restriction digests to entries in the web-based ribosomal database (RDP-II) using the phylogenetic analysis tool (PAT). Species match, fragment size (as base pair), total relative area percentage, and taxonomic classifications are provided.

\begin{tabular}{|c|c|c|c|c|c|c|}
\hline \multicolumn{7}{|c|}{ un-saturated soil } \\
\hline Species match & (Hha I) & (Msp I) & (Rsa I) & area\% & Phylum & Class \\
\hline Telluria chitinolytica & 78 & 490 & 470 & 7.9 & Proteobacteria & Betaproteobacteria \\
\hline Bordetella bronchiseptica/holmesii & 565 & 490 & 470 & 7.9 & Proteobacteria & Betaproteobacteria \\
\hline Chlorobium limicola & 90 & 455 & 470 & 7.1 & Chlorobi & Chlorobia \\
\hline Burkholderia 'SAP II' & 565 & 141 & 470 & 7.0 & Proteobacteria & Betaproteobacteria \\
\hline Desulfotomaculum halophilum & 565 & 161 & 470 & 5.6 & Firmicutes & Clostridia \\
\hline Spiroplasma citri/mirum/poulsonii & 72 & 540 & 470 & 5.5 & Firmicutes & Mollicutes \\
\hline Bacillus edaphicus & 565 & 139 & 474 & 4.8 & Firmicutes & Bacilli \\
\hline Stenotrophomonas maltophilia & 210 & 461 & 474 & 4.7 & Proteobacteria & Gammaproteobacteria \\
\hline Microvirgula aerodenitrificans & 567 & 429 & 474 & 4.3 & Proteobacteria & Betaproteobacteria \\
\hline Azoarcus indigens/str. S5b2 & 210 & 84 & 474 & 4.1 & Proteobacteria & Betaproteobacteria \\
\hline Thauera mz1t & 210 & 81 & 474 & 4.0 & Proteobacteria & Betaproteobacteria \\
\hline Nitrosomonas sp. & 567 & 490 & 882 & 3.4 & Proteobacteria & Betaproteobacteria \\
\hline Flavobacterium lutescens & 565 & 490 & 882 & 3.3 & Proteobacteria & Gammaproteobacteria \\
\hline Dechlorisoma suilla & 210 & 490 & 123 & 2.8 & Proteobacteria & Betaproteobacteria \\
\hline Streptomyces lividans/vellosus/spp. & 464 & 159 & 452 & 2.5 & Actinobacteria & Actinobacteria \\
\hline Microbacterium arborescens & 142 & 161 & 452 & 2.4 & Actinobacteria & Actinobacteria \\
\hline Arhodomonas aquaeolei & 565 & 141 & 882 & 2.4 & Proteobacteria & Gammaproteobacteria \\
\hline Sulfobacillus thermosulfidooxidans & 140 & 161 & 452 & 2.4 & Firmicutes & Bacilli \\
\hline Legionella pneumophila & 212 & 495 & 882 & 2.2 & Proteobacteria & Gammaproteobacteria \\
\hline Prevotella buccalis/oris & 101 & 495 & 481 & 2.2 & Bacteroidetes & Bacteroidetes \\
\hline Piscirickettsia salmonis & 567 & 495 & 882 & 2.0 & Proteobacteria & Gammaproteobacteria \\
\hline Shewanella frigidimarina & 76 & 495 & 882 & 1.9 & Proteobacteria & Gammaproteobacteria \\
\hline Ectothiorhodospira vacuolata & 78 & 139 & 882 & 1.6 & Proteobacteria & Gammaproteobacteria \\
\hline Halomonas halodenitrificans & 212 & 127 & 882 & 1.5 & Proteobacteria & Gammaproteobacteria \\
\hline Pseudomonas stutzeri & 565 & 461 & 882 & 1.4 & Proteobacteria & Gammaproteobacteria \\
\hline Methylocaldum szegediense & 210 & 71 & 882 & 1.0 & Proteobacteria & Gammaproteobacteria \\
\hline Frankia sp. & 346 & 140 & 442 & 0.9 & Actinobacteria & Actinobacteria \\
\hline Halorhodospira halochloris & 65 & 144 & 882 & 0.8 & Proteobacteria & Gammaproteobacteria \\
\hline Oceanospirillum japonicum & 565 & 89 & 882 & 0.8 & Proteobacteria & Gammaproteobacteria \\
\hline Marinobacter hydrocarbonoclasticus & 210 & 144 & 882 & 0.8 & Proteobacteria & Gammaproteobacteria \\
\hline Kingella denitrificans & 210 & 84 & 123 & 0.4 & Proteobacteria & Betaproteobacteria \\
\hline Abiotrophia adiacens & 210 & 69 & 893 & 0.3 & Firmicutes & Bacilli \\
\hline \multicolumn{7}{|c|}{ saturated soil } \\
\hline Species match & (Hha I) & (Msp I) & (Rsa I) & area\% & phylum & class \\
\hline Halobacillus/Sporosarcina & 60 & 148 & 471 & 30 & Firmicutes & Bacilli \\
\hline Leptothrix spp. & 203 & 136 & 471 & 24 & Proteobacteria & beta proteobacteria \\
\hline Clostridium spp. & 234 & 519 & 450 & 6 & Firmicutes & Clostridia \\
\hline Rhodococcus sp. str. & 663 & 138 & 79 & 6 & Actinonbacteria & Actinonbacteria \\
\hline Myxococcus/Mellittangium & 60 & 161 & 491 & 6 & Proteobacteria & delta proteobacteria \\
\hline Myxococcus coralloides & 91 & 161 & 491 & 5 & Proteobacteria & delta proteobacteria \\
\hline Roseobacter Shippagan & 60 & 442 & 423 & 4 & Proteobacteria & alpha proteobacteria \\
\hline Beijerinckia indica & 342 & 150 & 423 & 4 & Proteobacteria & alpha proteobacteria \\
\hline Rhodobacter/Afipia & 342 & 442 & 423 & 4 & Proteobacteria & alpha proteobacteria \\
\hline Sphingomonas/Porphyrobacter/Erythrobacter & 82 & 150 & 423 & 4 & Proteobacteria & alpha proteobacteria \\
\hline Methylosinus LW2 & 342 & 150 & 108 & 3 & Proteobacteria & alpha proteobacteria \\
\hline Saccharothrix australiensis & 663 & 128 & 79 & 2 & Actinobacteria & Actinobacteria \\
\hline Capnocytophaga canimorsus & 91 & 84 & 110 & 1 & Bacteroidetes & Flavobacteria \\
\hline
\end{tabular}




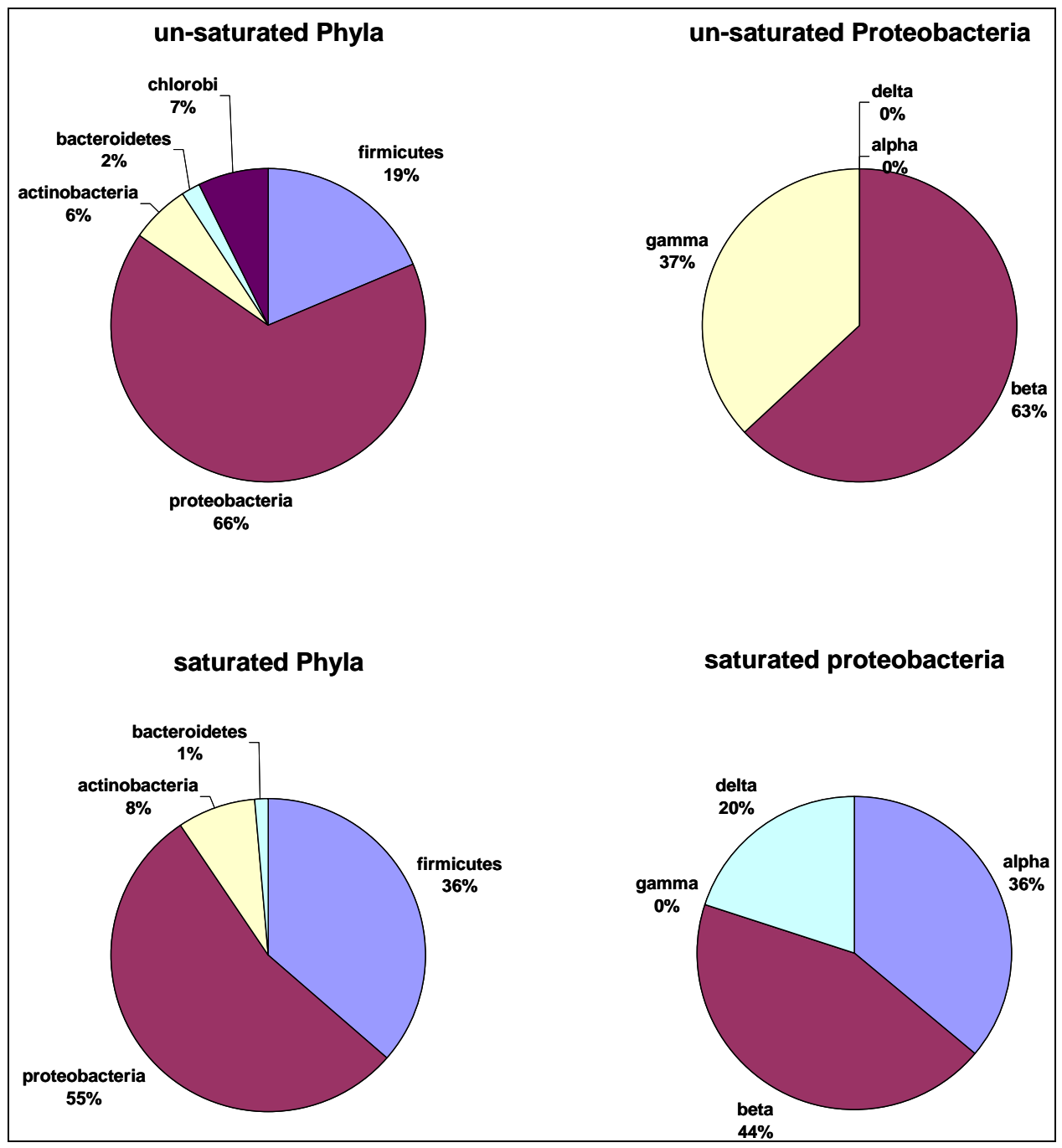

Figure 3. Distribution of bacteria phyla and bacterial classes within the proteobacteria phylum in saturated and unsaturated training range surface soils following $\mathbf{8 4 0}$ hours of incubation as determined by terminal restriction fragment length polymorphisms (T-RFLP). Identifications were obtained by running the phylogenetic analysis tool (PAT) against the (RDB-II) ribosomal database. Individual identifications are listed in Table 3. The analysis revealed an increase in the proportion of firmicutes and the emergence of alpha- and deltaproteobacteria in the saturated soil. A number of the bacteria identified within the saturated soil could be related to RDX biodegradation.

In addition to the two ureolytic organisms, Clostridia spp., Rhodococcus spp. and Beijerinckia sp. were identified in the saturated soil. All three genera of bacteria contain species known to utilize RDX as a sole source of carbon and/or 
nitrogen (Buchan et al. 2003; Seth-Smith et al. 2002). ${ }^{*}$ The emergence of other species of alpha- and delta-proteobacteria, i.e. Myхососcus, Methylosinus, Rhodobacter, and Sphingomonas, was also unique to the saturated soil. Although these organisms have not been directly tied to nitramine biodegradation, the latter three genera have all been tied to the biodegradation of aromatic compounds. Certain Rhodobacter and Sphingomonas species facilitate ring cleavage via the protocatchuate enzyme, whereas certain Methylosinus species can facilitate ring cleavage via a monooxygenase as well as oxidize a variety of aliphatic compounds (Green and Dalton 1989, Buchan et al. 2001, Wattian et al. 2001). Within the saturated soil, the majority of organisms identified showed traits related to xenobiotic biodegradation, if not nitramine biodegradation specifically. These identifications correspond to an RDX half-life of four days.

Although the development of the microbial community within the saturated soil coincided with a rapid rate of RDX biodegradation, the data are not sufficient to determine if the development was in direct response to the contaminant.

Whether or not the resulting community would have formed in the absence of RDX is unclear. Nevertheless, maintaining this soil in a saturated state for 840 hours resulted in a complete biotransformation of the added aqueous RDX, seven times greater than that observed in the unsaturated soil.

Of the 32 unique genera or species of bacteria detected by T-RFLP analysis in the 840-hour unsaturated soil, no single species was identified that is known to degrade RDX in pure culture. However, identifications of T-RFLP fragments are based primarily on cultured organisms. Since only $1-10 \%$ of the in situ microbiota is culturable, the current databases can only identify $1-10 \%$ of the bacteria present in a given soil. Therefore, it is not possible to determine what fraction of the added RDX was transformed by unidentified organisms. In addition, no single genus of bacteria was identified in both the saturated and unsaturated soil. Considering the common origin of the material, this result indicates that the TRFLP assay may have been influenced by cell abundance, and the characterizations obtained may be best described as descriptions of the most abundant organisms present.

Even though no species were identified that are known to degrade RDX in the unsaturated soil, some species were identified that have been observed to degrade other environmental pollutants. Burkholderia spp. have been isolated that show the ability to biodegrade 2,4-dinitrotoluene. Burkholderia was one of the more abundant species detected in our tests (Table 3). Strains of the betaproteobacteria Bordettella and the gamma-proteobacteria Pseudomonas stutzeri are capable of degrading a variety of xenobiotics, including aromatic compounds

${ }^{*}$ Also, personal communication, Dr. Neal Adrian and Dr. Herb Fredrickson, ERDC. 
(Eriksson et al. 2003, Spanggord et al. 1991). In short, the unsaturated soil may have also fostered the development of a degradative microbial community. However, compared to the saturated soil, the unsaturated soil was less amenable to RDX biotransformation, as indicated by the rate at which the RDX was biotransformed and by the diversity and types of bacteria identified.

One unique characteristic of the unsaturated soil suggests the importance of trophic interactions in microbial community development. An increase in total microbial biomass at 840 hours into the incubation coincided with an increase in the percentage of eukaryotic PLFA biomarkers, specifically the $\omega 6$ or microfauna PLFA (Fig. 4). This increase corresponded with a decrease in the percentage of Gram-negative ( $\omega 7$ series) PLFAs. The other Gram-negative, Gram-positive, and actinomycete PLFA biomarkers showed little change in percentage as a result of the eukaryotic bloom. A visual inspection of the soil revealed an abundance of ciliates, amoeba, and flagellates (data not shown). Ronn et al. (2002) have suggested that medium-size Gram-negative bacteria are often preferentially grazed over other bacterial types. Since, in general, two biosynthetic pathways are utilized to produce the different monounsaturated fatty acid series $(\omega 7$ series and other series), the detected difference within the Gram-negative bacterial community likely reflects a change in taxonomy.

Others have shown that size-selective grazing can have significant effects on the biodegradation of xenobiotics (Kinner et al. 1998, Bouchez et al. 2000). These effects include a stimulatory effect by maintaining bacterial metabolic activity, an inhibitory effect by reducing selective cell numbers, or no effect caused by grazing of non-RDX related bacteria. In the unsaturated microcosms, the rate of RDX loss at 840 hours $\left(6.2 \pm 1.1 \mu \mathrm{g} \mathrm{kg}^{-1} \mathrm{~h}^{-1}\right)$ was no different than that recorded at 504 hours $\left(4.5 \pm 1.5 \mu \mathrm{g} \mathrm{kg}^{-1} \mathrm{~h}^{-1}\right)$ or 168 hours $\left(4.1 \pm 11.7 \mu \mathrm{g} \mathrm{kg}^{-1}\right.$ $\mathrm{h}^{-1}$ ). This result indicates either that protozoan grazing had little to no effect on RDX loss or that an effect was beginning to emerge. Nevertheless, the bloom in microfauna PLFA biomarkers coincident with a significant loss in a subpopulation of Gram-negative bacteria suggests that microbial community development in the unsaturated soil was influenced to a certain extent by trophic interactions.

The development of novel assays is beginning to provide some insight into the flow of xenobiotic carbon and/or nitrogen into specific biomarkers. Recent advances in the use of stable isotopes have allowed researchers to monitor the incorporation of contaminant carbon and nitrogen into specific PLFA and DNA/RNA fragments. These data are just beginning to shed light on which members of a microbial community are specifically involved in contaminant catabolism (Boschker and Middleburg 2002, Manefield et al. 2002). 


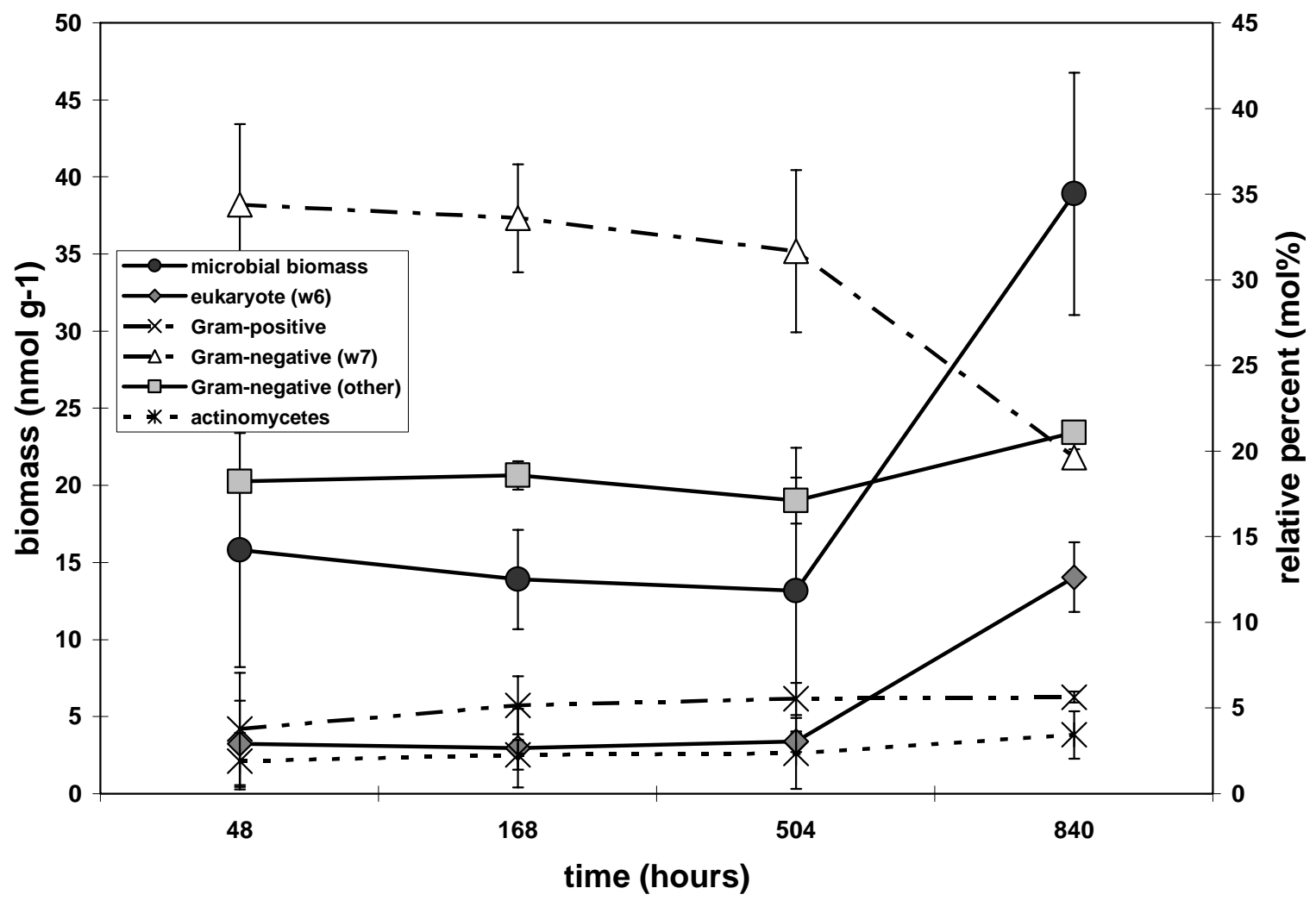

Figure 4. Changes in total microbial biomass and relative percentages of bacterial PLFA in an unsaturated training range surface soil following 840 hours of incubation in the presence of $10 \mathrm{mg} \mathrm{kg}^{-1}$ of aqueous RDX. Total microbial biomass represents the sum of all PLFAs detected normalized to the gram wet weight of soil extracted. Signature biomarker PLFAs are grouped as indicated in Table 1, with each data point representing the sum of all PLFAs (expressed as a mole \%) within a group. An increase in total microbial biomass corresponded with an increase in microfaunal $(\omega 6)$ eukaryotic signature biomarkers and a decrease in a specific subset ( $\omega 7$ series) of Gram-negative bacterial biomarkers. The data may reflect selective grazing by protozoa. 


\section{CONCLUSIONS}

Soil moisture tension had a significant effect on the development of indigenous microbes incubated in the presence of aqueous RDX. Saturated soils fostered the development of a reduced environment that supported the complete biotransformation of the added RDX. The resulting microbial community was enriched in firmicutes and alpha- and delta proteobacteria. Specific bacterial genera known to degrade RDX were identified (i.e. Clostridium spp., Rhodococcus spp., and Beijerinckia sp.), as well as other genera with associated biodegradation capabilities (i.e. denitrification and ring cleavage). However, the most abundant genera identified were the Halobacillus/Sporosarcina, which have the ability to affect soil $\mathrm{pH}$ through the release of ammonium ions, potentially leading to alkaline hydrolysis of the added RDX. The community analysis indicated that a suite of complementary biodegradation processes might well have been active. The unsaturated soils exhibited a significantly different succession and endpoint microbial community characterized by a considerably lower rate and extent of RDX biotransformation. The aerobic nature of the soil fostered the development of a diverse bacterial community with a capacity for contaminant biodegradation, if not one ideally suited to RDX biotransformation. The results indicate that soil moisture tension can influence microbial community development and the associated capacity to degrade RDX. Estimates of the biodegradation capacity of a soil would benefit from the quantification of microbial responses under a range of soil moisture tensions. 


\section{REFERENCES}

Agency for Toxic Substances and Disease Registry (ATSDR) (1995) Toxicological profile for RDX. Atlanta, Georgia: U.S. Department of Health and Human Services, Public Health Service.

Balkwill, D.L., F.R. Leach, J.T. Wilson, J.F. McNabb, and D.C. White (1988) Equivalence of microbial biomass measures based on membrane lipid and cell wall components, adenosine triphosphate, and direct counts in subsurface sediments. Mirobial Ecology, 16: 73-84.

Boschker, H.T.S., and J.J. Middleburg (2002) Stable isotopes and biomarkers in microbial ecology. FEMS Microbiological Ecology, 40: 85-95.

Bouchez, T., D. Patureau, P. Dabert, S. Juretschko, J. Dore, P. Deelgenes, R. Moletta, and M. Wagner (2000) Ecological study of a bioaugmentation failure. Environmental Microbiology, 2(2): 179-190.

Buchan, A., E.L. Neidle, and M.A. Moran (2001) Diversity of the ringcleaving dioxygenase gene pcaH in a salt marsh bacterial community. Applied Environmental Microbiology, 67(12): 5801-5809.

Bhushan, B., S. Trott, J.C. Spain, A. Halasz, L. Paquet, and J. Hawari (2003) Biotransformation of hexahydro-1,3,5-trinitro-1,3,5-triazine (RDX) by a rabbit liver cytochrome P450: Insight into the mechanism of RDX biodegradation by Rhodococcus sp. strain DN22. Applied Environmental Microbiology, 69: 1347-1351.

Boopathy, R., J. Manning, and C.F. Kulpa (1998) Biotransformation of explosives by anaerobic consortia in liquid culture and in soil slurry. International Biodeterioration and Biodegradation, 41: 67-74.

Carpenter-Boggs, L., A.C. Kennedy, and J.P. Reganold (1998) Use of phospholipids fatty acids and carbon source utilization patterns to track microbial community succession in developing compost. Applied Environmental Micobiology, 64(10): 4062-4064.

Conklin, A.R. (2002) Soil microorganisms. Proceedings of the Conference on Soil Sediment and Water, Association for Environmental Health and Sciences, Amherst, Massachusetts.

Eriksson, M., E. Sodersten, Y. Zhontang, G. Dalhamma, and W.W. Mohn (2003) Degradation of polycyclic aromatic hydrocarbons at low temperature under aerobic and nitrate-reducing conditions in enrichment cultures from northern soils. Applied Environmental Micobiology, 69(1): 275-284. 
Green, J., and H. Dalton (1989) Substrate specificity of soluble methane monooxygenase: Mechanistic implications. Journal of Biological Chemistry, 264: 17,698-17,703.

Gruntzig, V., B. Stres, H.L. Ayala del Rio, and J.M. Tiedje (2002) Improved protocol for T-RFLP by capillary electrophoresis. Center for Microbial Ecology, Michigan State Univ., East Lansing, Michigan. http://rdp.cme.msu.edu/html/trflp_jul02.html.

Guiot, S.R., C.F. Shen, L. Paquet, J. Breton, and J. Hawari (1999) Pilot-scale anaerobic bioslurry remediation of RDX and HMX contaminated soils. In Bioremediation of Nitroaromatic and Haloaromatic Compounds (B. Alleman and A. Leeson, ed.). Battelle Press, Columbus, Ohio, 5(7): 15.

Hawari, J. (2000) Biodegradation of RDX and HMX: From basic research to field application. In Biodegradation of Nitroaromatic Compounds and Explosives (J.C. Spain, J.B. Hughes, and H.-J. Kanckmuss, ed.). Boca Raton, Florida: CRC Press, p. 277-310.

Hawari, J., S. Beaudet, A. Halasz, S. Thiboutot, and G. Ampleman (2000) Microbial degradation of explosives: biotransformation versus mineralization. Applied Microbiology and Biotechnology, 54: 605-618.

Kinner, N.E., R.W. Harvey, K. Blakeslee, G. Novarino, and L.D. Meeker (1998) Size-selective predation on groundwater bacteria by nanoflagellates in an organic-contaminated aquifer. Applied Environmental Microbiology, 64(2): 618625 .

Lechevalier, H., and M.P. Lechevalier (1988) Chemotaxonomic use of lipids An overview. In Microbial Lipids, Volume 1 (C. Ratledge and S.G. Wilkinson, ed.). San Diego, California: Academic Press, p. 869-902.

Light, W.C., G.G. Wilber, and W.W. Clarkson (1997) Biological treatability of RDX-contaminated soil. Proceedings of the Purdue Industrial Waste Conference, vol. 15, p. 135-148.

Manefield, M., A.S. Whiteley, R.I. Griffiths, and M.J. Bailey (2002) RNA stable isotope probing, a novel means of linking microbial community function to phylogeny. Applied Environmental Microbiology, 68(11): 5367-5373.

McCormick, N.G., J.H. Cornell, and A.M. Kaplan (1981) Biodegradation of hexahydro-1,3,5-trinitro-1,3,5-triazine. Applied Environmental Microbiology, 42: 817-823. 
Onderdonk, A.B., and M. Sasser (1995) Gas-liquid and high-performance liquid chromatographic methods for the identification of microorganisms. In Manual of Clinical Microbiology (E.J. Baron, .R. Murray, M.A. Pfaller, F.C.

Tenovar, R.H. Yolken, ed.). Sixth edition. Washington D.C.: American Society for Microbiology, p. 123-129

Pinkart, H.C., D.B. Ringelberg, Y.M. Piceno, S.J. McNaughton, and D.C. White (2002) Biochemical approaches to biomass measurements and community structure analysis. In Manual of Environmental Microbiology (C.J. Hurst, R. Crawford, G. Knudsen, M.J. McInerney, and L.D. Stezenbach, ed.). Second edition. Washington, D.C.: American Society for Microbiology Press, p. 101-113.

Pinkart, H.C., R. Devereux, and P.J. Chapman (1998) Rapid separation of microbial lipids using solid phase extraction columns. Journal of Microbiology Methods, 34: 9-15.

Price, C.B., J.M. Brannon, S.L. Yost, and C.A. Hayes (2001) Adsorption and transformation of RDX in low-carbon aquifer soils. Technical Report ERDC/EL TR-01-19, Environmental Laboratory, U.S. Army Engineering Research and Development Center, Vicksburg, Mississippi.

Ringelberg, D.B., J.W. Talley, E.J. Perkins, S.G. Tucker, R.G. Luthy, E.J. Bower, and H.L. Fredrickson (2001) Succession of phenotypic, genotypic and metabolic community characteristics during the in vitro bioslurry treatment of PAH-contaminated sediments. Applied Environmental Microbiology, 67(4): $1542-1550$.

Ringelberg, D.B., C.M. Reynolds, M.E. Walsh, and T.F. Jenkins (2003) RDX loss in a surface soil under saturated and well drained conditions. Journal of Environmental Quality, 32: 1244-1249.

Rock, C.O., and K.E. Cronan, Jr. (1985) Lipid metabolism in prokaryotes. In Biochemistry of Lipids and Membranes (D.E. Vance and J.E. Vance, ed.). Menlo Park, California: The Benjamin/Cummings Publishing Company, p. 81-83 and $110-113$.

Ronn, R., A.E. McCaig, B.S. Griffiths, and J.I. Prosser (2002) Impact of protozoan grazing on bacterial community structure in soil microcosms. Applied Environmental Microbiology, 68(12): 6094-6105.

Seth-Smith, H.M.B., S.J. Rosser, A. Basran, E.R. Travis, E.R. Dabbs, S. Nicklin, and N.C. Bruce (2002) Cloning, sequencing, and characterization of the hexahydro-1,3,5-trinitro-1,3,5-triazine degradation gene cluster from Rhodococcus rhodochrous. Applied Environmental Microbiology, 68: 47644771. 
Sheremata, T.L., A. Halasz, L. Paquet, S. Thiboutot, G. Ampleman, and J. Hawari (2001) The fate of the cyclic nitramine explosive RDX in natural soil. Environmental Science and Technology, 35: 1037-1040.

Sheremata, T.W., and J. Hawari (2000) Biodegradation of RDX by the white rot fungus Phanerochaete chrysosporium to carbon dioxide and nitrous oxide. Environmental Science and Technology, 34: 3384-3388.

Spanggord, R.J., R.W. Mabey, T. Mill, T.W. Chou, J.H. Smith, S. Lee, and D. Roberts (1983) Environmental fate studies on certain munitions wastewater constituents: Phase IV--Lagoon model studies. Prepared by SRI International, Menlo Park, California. Document AD-A133987, U.S. Army Medical Research and Development Command, Fort Detrick, Maryland.

Spanggord, R.J., J.C. Spain, S.F. Nishino, and K.E. Mortlemans (1991) Biodegradation of 2,4-dinitrotoluene by a Pseudomonas sp. Applied Environmental Microbiology, 57: 3200-3205.

Speitel, G.E., T.L. Engels, and D.C. McKinney (2001) Biodegradation of RDX in unsaturated soil. Bioremediation Journal, 5(1): 1-11.

Stahl, J.D., B. Van Aken, M.D. Cameron, and S.D. Aust (2001) Hexahydro1,3,5-trinitro-1,3,5-triazine (RDX) biodegradation in liquid and solid-state matrices by Phanerochaete chyrsosporium. Bioremediation Journal, 5(1): 13-25.

Wattian, P., L. Bastiaens, R. van Herwijnen, L. Paal, J.R. Parsons, M.E. Renard, D. Springael, and G.R. Cornelis (2001) Fluorene degradation by Sphingomonas sp. LB126 proceeds through protocatchuate acid: A genetic analysis. Research in Microbiology, 152(10): 861-872.

White, D.C., and D.B. Ringelberg (1998) Signature lipid biomarker analysis. In Techniques in Microbial Ecology (R.S. Burlage, R. Atlas, D. Stahl, G. Geesey, and G. Sayler, ed.). New York: Oxford University Press, Inc., p. 255-272.

Zhao, J.S., C.W. Greer, S. Thiboutot, G. Ampleman, and J. Hawari (2004) Biodegradation of the nitramine explosives hexahydro-1,3,5-trinitro-1,3,5triazine and octahydro-1,3,5,7-tetranitro-1,3,5,7-tetrazocine in cold marine sediment under anaerobic and oligotrophic conditions. Canadian Journal of Microbiology, 50(2): 91-96. 


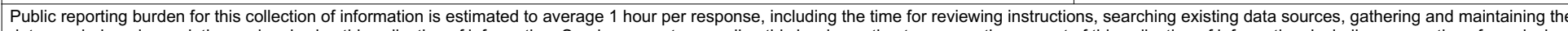

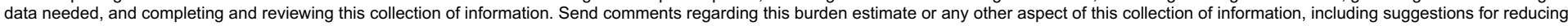

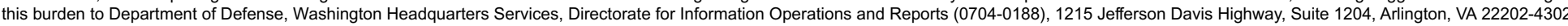

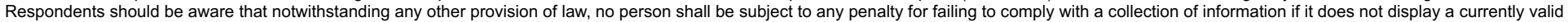
OMB control number. PLEASE DO NOT RETURN YOUR FORM TO THE ABOVE ADDRESS.
1. REPORT DATE (DD-MM-YY)
2. REPORT TYPE
March 2005
Technical Report

4. TITLE AND SUBTITLE

3. DATES COVERED (From - To)

5a. CONTRACT NUMBER

Microbial Community Shifts Associated with

5b. GRANT NUMBER

RDX Loss in a Saturated and Well-Drained

Surface Soil

5c. PROGRAM ELEMENT NUMBER

6. AUTHOR(S)

David B. Ringelberg, Charles M. Reynolds, Karen L. Foley, and Lawrence B. Perry

5d. PROJECT NUMBER

5e. TASK NUMBER

5f. WORK UNIT NUMBER

8. PERFORMING ORGANIZATION REPORT

7. PERFORMING ORGANIZATION NAME(S) AND ADDRESS(ES)

U.S. Army Engineer Research and Development Center

Cold Regions Research and Engineering Laboratory

72 Lyme Road

ERDC/CRREL TR-05-4

Hanover, New Hampshire 03755

9. SPONSORING/MONITORING AGENCY NAME(S) AND ADDRESS(ES)

U.S. Army Corps of Engineers

Washington, DC 20314-1000

11. SPONSOR / MONITOR'S REPORT NUMBER(S)

\section{DISTRIBUTION / AVAILABILITY STATEMENT}

Approved for public release; distribution is unlimited.

Available from NTIS, Springfield, Virginia 22161.

\section{SUPPLEMENTARY NOTES}

\section{ABSTRACT}

Low-order, incomplete detonations can deposit hexahydro-1,3,5- trinitro- 1,3,5-triazine (RDX) into training range surface soils. In previous work, we showed that aqueous RDX could be rapidly biotransformed (4-day half-life) in water-saturated surface soil. However, biotransformation rates in the same soil at 0.15 -bar soil moisture tension were significantly slower (28-day half-life). Here we report on the microbial community composition associated with the deposited RDX under the differing soil moisture tensions. Phospholipid fatty acid (PLFA) and terminal fragment length polymorphism (T-RFLP) profiles were used to quantify the in situ microbiota. The rapid biotransformation of RDX in the saturated soil was coincident with an endpoint microbial community containing firmicutes (36\%), proteobacteria (54\%), actinobacteria ( $8 \%)$, and bacteroidetes (1\%). The unsaturated soil contained a greater number of genera (2.5 times that of the saturated soil) within similar phyla (19\% firmicutes, $66 \%$ proteobacteria, $6 \%$ actinobacteria, $2 \%$ bacteroidetes, and $7 \%$ chlorobi). Significant differences between the two moisture contents occurred within the proteobacteria and firmicutes. A 37\% gamma-class in unsaturated soil shifted to $56 \%$ alpha- and delta-classes in saturated soil. Total firmicutes increased from 19\% unsaturated to $36 \%$ saturated. PLFA profiles extracted from saturated soil showed an increase in the relative abundance of only a few fatty acids (n16:0, n18:0, i15:0, a15:0, b16:1w7c, n18:1w9c, n18:1w7c, and cy19:0). However, these PLFAs are consistent with Gram-negative proteobacteria (n16:1w7c, n18:1w9c, and n18:1w7c) and firmicutes (i15:0 and a 15:0). Based on these results, we hypothesize that the saturated soil led to the development of alpha/deltaproteobacteria and firmicute subpopulations and that these populations were primarily responsible for the observed biological transformation of RDX.

\begin{tabular}{|c|c|c|c|c|c|}
\hline 15. SUBJECT TERMS & \multicolumn{2}{|c|}{$\begin{array}{l}\text { Microbial communities } \\
\text { PLFA } \\
\text { RDX }\end{array}$} & $\begin{array}{l}\text { Soil moisture potential } \\
\text { T-RFLP }\end{array}$ & & \\
\hline \multicolumn{3}{|c|}{ 16. SECURITY CLASSIFICATION OF: } & \multirow{2}{*}{\begin{tabular}{|l|} 
17. LIMITATION OF \\
OF ABSTRACT
\end{tabular}} & \multirow{2}{*}{$\begin{array}{l}\text { 18. NUMBER } \\
\text { OF PAGES }\end{array}$} & 19a. NAME OF RESPONSIBLE PERSON \\
\hline a. REPORT & b. ABSTRACT & c. THIS PAGE & & & 19b. TELEPHONE NUMBER (include area code) \\
\hline $\mathrm{U}$ & $\mathrm{U}$ & $\mathrm{U}$ & $\mathrm{U}$ & 24 & \\
\hline
\end{tabular}

